and steady trend of reversal of sex ratio is apparent. ${ }^{2-5}$ Miller $e t$ al investigated the subsites of gastric ulcers and also found a higher proportion of women with type I ulcers. Type I gastric ulcer is thought to be pathophysiologically different from types II and III. Hyposecretion and bile reflux have been associated with type I ulcers, and hypersecretion with types II and III. Our study shows that the increase of gastric ulcer in women is due solely to the conspicuous increase in type I ulcers.

The reason(s) for the reversal of sex ratio is not clear. It is unlikely to be explained by genetic factors. The steady rise in incidence of bronchial carcinoma and cirrhosis of the liver in past decades has been correlated to the increase in cigarette smoking and alcohol consumption by women. Theoretically alcohol damages the "gastric mucosal barrier" either by itself or synergistically with other ulcerogenic substances; and smoking is associated with delayed ulcer healing as well as a greater risk of ulcer relapse after healing. Drugs like aspirin, steroids, and other non-steroidal anti-inflammatory drugs have been implicated in gastric ulceration. In a retrospective study such as ours the list and quantities of all drugs used by patients are notoriously inaccurate. A prospective study on effect of drugs at the time of diagnosis of the ulcer may yield more meaningful results. These factors, however, should be considered to explain the large number of women with type I gastric ulcers.

${ }^{1}$ Langman MJS. Changing patterns in the epidemiology of peptic ulcer. Clin Gastroenterol 1973;2:219-26.

${ }^{2}$ Madanagopalan N, Subramaniam R, Kirshanan MN. Comparative study of operated cases of peptic ulcer in Madras in the 1940s and 1960s. Gut 1968;9:69-74.

${ }^{3}$ Comfort MW, Priestley JT, Dockerty MD, et al. The small benign and malignant gastric lesions. Surg Gynecol Obstet 1957;105:435-48.

${ }^{4}$ Miller LJ, Resseguie LJ, Taylor WF, Malagelada JR. Cholecystectomy and gastric ulcer-an etiologic relationship ? Mayo Clin Proc 1980;55: 255-7.

${ }^{5}$ Billington BP. Observations from New South Wales on the changing incidence of gastric ulcer in Australia. Gut 1965;6:121-33.

(Accepted 29 fune 1982)

School of Medicine, University of Auckland, Auckland, New Zealand $S$ P LEE, PHD, FRACP, senior lecturer in medicine

\section{Endocarditis due to viridans-type streptococci tolerant to beta-lactam antibiotics: therapeutic problems}

A patient with subacute bacterial endocarditis caused by a viridanstype streptococcus failed to respond to a $\beta$-lactam antibiotic despite apparent sensitivity of the organism to the drug used. Investigation showed that the organism was tolerant to the antimicrobial agent. This phenomenon in which the ratio between the concentration of antibiotic which kills an organism (minimum bactericidal concentration) and the concentration that inhibits its growth (minimum inhibitory concentration) is 10 or greater is recognised among viridans streptococci in vitro, ${ }^{1}$ but therapeutic problems due to such streptococci have not hitherto arisen.

We describe the case together with another in which a similar tolerant organism was identified.

\section{Case reports}

Case 1-A 9-year-old girl with Down's syndrome and congenital heart disease was admitted with signs of subacute bacterial endocarditis. All blood cultures grew Streptococcus mutans. Two weeks after beginning treatmen with cefuroxime she was still intermittently feverish and her murmur was louder. Studies on the organism (table) showed a gross disparity between the minimum inhibitory and minimum bactericidal concentrations of cefuroxime. Furthermore, even undiluted serum taken from the patient half an hour after a dose failed to kill the organism. With $1 \mathrm{mg}$ gentamicin per l, however, the minimum bactericidal concentration of cefuroxime fell to $0.02 \mathrm{mg} / \mathrm{l}$. Treatment was changed to cefuroxime and gentamicin; she rapidly improved, and remained well.

Case 2-A 15-year-old boy with a ventricular septal defect was admitted with endocarditis after the isolation of Str mutans from blood cultures.
Penicillin and gentamicin were started, with the intention of stopping the gentamicin when a satisfactory bactericidal concentration of penicillin had been shown in vitro. The organism, however, was tolerant to penicillin. Since the killing titre of his serum was satisfactory, treatment was continued with the combination. After four weeks a rash developed and

Minimum inhibitory and minimum bactericidal concentrations (MIC and MBC) determined by broth dilution. Values expressed in $\mathrm{mg} / \mathrm{l}$

\begin{tabular}{|c|c|c|c|c|}
\hline \multirow{2}{*}{ Antibiotic } & \multicolumn{2}{|c|}{ Case 1} & \multicolumn{2}{|c|}{ Case 2} \\
\hline & MIC & MBC & MIC & $\mathrm{MBC}$ \\
\hline Penicillin & 0.03 & $\geqslant 1000$ & 0.04 & 128 \\
\hline Cefuroxime & 0.04 & $\geqslant 5$ & $0 \cdot 1$ & $\geqslant 12.5$ \\
\hline $\begin{array}{l}\text { Vancomycin } \\
\text { Gentamicin }\end{array}$ & & & & $\geqslant 10 \cdot 0$ \\
\hline $\begin{array}{l}\text { Gentamicin } \\
\text { Erythromycin }\end{array}$ & $\begin{array}{l}2.5 \\
0.06\end{array}$ & $\geqslant 1$ & 0.02 & $1 \cdot 2$ \\
\hline
\end{tabular}

cefuroxime was substituted for the penicillin. As the rash persisted, vancomycin alone was instituted. The organism was also tolerant to that drug however, and the course was concluded with erythromycin. The table summarises the bacteriological findings. The patient remained well four months later.

\section{Comment}

Our case 1 was an example of therapeutic failure due to tolerance, and case 2 an example of the difficulties that may arise in choosing appropriate antibiotics when tolerance is shown in vitro. While in many infections bacteriostatic antibiotics are effective, it is accepted that bactericidal drugs are necessary for endocarditis. Tolerance to $\beta$-lactam antibiotics has led to treatment failure in endocarditis caused by group C streptococci, ${ }^{2}$ Str faecalis, ${ }^{3}$ and Staphylococcus epidermidis. ${ }^{4}$ Most cases of endocarditis, however, are still caused by viridans-type streptococci, for which the choice of $\beta$-lactam antibiotics is made with confidence. Cross-tolerance between penicillins, cephalosporins, and vancomycins, all active on cell-wall synthetic pathways, is common but not invariable. It is suggested that while the direct action of $\beta$-lactam antibiotics inhibits growth, subsequent cell lysis depends on a lytic enzyme from the organism itself-a murein hydrolase -and that tolerance may be linked with the activity of this enzyme. In their study on penicillin-tolerant viridans streptococci, Holloway et $a l^{1}$ investigated organisms from children with cardiac disease receiving penicillin prophylaxis to cover dental surgery. This treatment increases the proportion of resistant strains as measured by minimum inhibitory concentrations, and of the $71 \%$ of viridans strains with inhibitory concentrations in the sensitive range, $19 \%$ were tolerant. It is perhaps surprising that therapeutic problems are so rare. Tolerance must be considered when reviewing patients who fail to respond to $\beta$-lactam antibiotics in endocarditis.

Cross-tolerance should be borne in mind when choosing alternative antibiotics. In both of our cases, however, adding an aminoglycoside was successful both therapeutically and in vitro in reducing the minimum bactericidal concentration to close to the minimum inhibitory concentration.

We thank Dr G Colman, of the Streptococcal Reference Unit, Colindale, for identifying the organisms, and Drs T G Feest and J H Tripp for allowing us to report these cases.

${ }^{1}$ Holloway Y, Dankert J, Hess J. Penicillin tolerance and bacterial endocarditis. Lancet 1980; i:589.

2 Portnoy D, Wink I, Richards GK, Blanc MZ. Bacterial endocarditis due to a penicillin-tolerant group C streptococcus. Can Med Assoc $\mathcal{F} 1980$ 122:69-75.

${ }^{3}$ McDonald M, Miles H, Hart D, Sonenberg N. Penicillin tolerance in Streptococcus faecalis. Lancet 1980;ii:321.

4 Arthur JD, Bass JW, Keiser JF, Harden LB, Brown SL. Nafcillintolerant Staphylococcus epidermidis endocarditis. $\mathcal{F} A M A \quad 1982 ; \mathbf{2 4 7}$ : 487-8.

${ }^{5}$ Horne D, Tomasz A. Tolerant response of Streptococcus sanguis to beta-lactams and other cell wall inhibitors. Antimicrob Agents Chemothe $1977 ; 11: 888-96$

(Accepted 29 fune 1982)

Public Health Laboratory, Heavitree, Exeter EX2 5AD

A W ANDERSON, MB, BCHIR, senior registrar, department of microbiology J G CRUICKSHANK, MD, FRCPATH, consultant microbiologist 